\title{
Viral Binding Proteins as Antibody Surrogates in Immunoassays of Cytokines
}

BioTechniques 32:160-171 (January 2002)

\author{
Hongdong Bai, R. Mark L. \\ Buller, Nanhai Chen, and \\ Michael D.P. Boyle ${ }^{1}$ \\ St. Louis University Health \\ Sciences Center, St. Louis, MO, \\ and ${ }^{1}$ Medical College of Ohio, \\ Toledo, OH, USA
}

\begin{abstract}
Cytokines are pivotal to a balanced innate or cell-mediated immune response, can be indicative of disease progression and/or resolution, and are being evaluated as therapeutics. There is a need to purify and/or to measure key cytokines rapidly with accuracy, precision, and sensitivity. The current assay technologies, which are based on RT-PCR, immunoassays, or bioassays, are limited in their use in the clinic, in particular because of the long time (1-3 h) required to carry out the assays. An alternative approach explored here is the use of pathogen-encoded cytokine-binding proteins, which have $K_{d}$ in the nanomolar range. It is anticipated that pathogens have evolved binding proteins, antagonists, and/or specific neutralizing phenotypes directed against key signaling and effector molecules involved in the multifaceted host defense system. Thus, by screening the genomes of a wide range of microbial agents, we would expect to find coding sequences for binding proteins for the most int portant cytokines. Consistent with this view is the identification of poxvirus genes encoding binding activities for TNF, type I and type II interferons, interleukin (IL)-1 $\beta, I L-18$, and $\beta$-chemokines. These high-affinity receptors
\end{abstract}

have the potential to act as surrogate antibodies in a number of applications in cytokine quantification and purification and could be potentially useful reagents to com plement the existing panel of anti-cytokine, monoclonal, polyclonal, or engineered antibodies that are currently available.

\section{CYTOKINE DETECTION METHODOLOGIES}

Cytokines are soluble protein mediators of immune function that are pivotal to a balanced innate or cell-mediated immune response. Since cytokine levels can be indicative of disease progression and/or resolution, and in a growing number of situations cytokines are being evaluated as therapeutics, there is a common need in both basic and applied research to purify and/or to measure key cytokines rapidly with accuracy, precision, sensitivity, and at low cost. Table 1 summarizes the current methods for measuring cytokine levels.

Efficient methods for monitoring cytokine levels will facilitate the diagnosis and/or treatment of many disease states, and thus will be critical to the efficient clinical delivery of medicine. The need for reliable, extremely rapid (<45 min) cytokine assays is well recognized. Currently, the assay systems based on antibodies have encountered problems with specificity, reproducibility, and assay time. Novel methods to quantify and purify cytokines are expected to expand as molecular medicine becomes a more refined science.

\section{Cytokine mRNA Measurements}

Cytokine levels can be estimated by measuring the cellular cytokine mRNA levels by either ribonuclease protection or RT PCR-based assays. Both assays are able to simultaneously analyze RNA levels for multiple cytokines in cell extracts. These RNA-based assays are very labor intensive, extremely sensitive to variations in experimental conditions (e.g., the presence of RNases), and are time consuming. Another major drawback is the lack of an absolute correlation between the levels of cytokine mRNA and protein. This is especially true with the measurement of cytokine levels in serum where tissue fixed cells may contribute to the circulating cytokine, but their cytokine mRNA would be absent from peripheral blood lym phocytes specimens.

\section{Bioassay}

The first bioassays were based on primary cells taken directly from the hematopoietic/immune system; however, difficulties in purifying the responding cells to homogeneity and large standard deviations among assays using different donors affected their utility. The availability of continuously grow ing cell lines that were responsive to cytokines and the development of receptor-transfected cell lines have permitted the development of more specific assays that are easier to perform and allow the measurement of the levels of biologically active cytokines in various 
Table 1. Characteristics of Cytokine Detection Methodologies

\begin{tabular}{|lllll|}
\hline Considerations & \multicolumn{1}{c}{ RT-PCR } & \multicolumn{1}{c}{ Bioassay } & \multicolumn{1}{c|}{ ELISA } & Microfluorimetry \\
\hline $\begin{array}{l}\text { Affinity of Capture } \\
\text { Reagents }\end{array}$ & Indirect measure & $\sim 10^{-9} \mathrm{M}$ & $10^{-6}-10^{-8} \mathrm{M}$ & $10^{-6}-10^{-8} \mathrm{M}$ \\
$\begin{array}{l}\text { Assay Specificity } \\
\text { Assay Speed }\end{array}$ & Excellent & Variable & Variable & Variable \\
$\begin{array}{l}\text { Cytokines Measured } \\
\text { in One Assay }\end{array}$ & $>3 \mathrm{~h}$ & $24 \mathrm{~h}$ & $>3 \mathrm{~h}$ & $\sim 1 \mathrm{~h}$ \\
$\begin{array}{l}\text { Reagent Preparation } \\
\text { Many }\end{array}$ & Recombinant & Cell culture & One & Many \\
Lot-to-lot Variations & Little & One & In animal/cell culture & In animal/cell culture \\
Reagent Costs & Expensive & Expensive & Expensive & Biological variation \\
Assay Labor Cost & High & High & High & in antibody preparations \\
Sample Preparation Time & Slow & Fast & Fast & High \\
\end{tabular}

samples. The cell response to the cytokine of choice can be measured in a number of ways, including proliferation, anti-proliferation, cytotoxicity, chemotaxis, inhibition of virus cytopathic effect, and the induction of secondary molecules including cell surface or secreted proteins (46). The major strength of the bioassay is that it provides estimates of biologically active cytokines, whereas immunoassays measure both biologically active and inactive cytokines. The bioassay, however, has a number of shortcomings. The assay can show sensitivity to nonspecific inhibition that is due to serum proteins in the sample. Also, the responding cell is usually sensitive to multiple cytokines requiring the inclusion of specific antibodies to the cytokine of interest to provide the necessary assay specificity. Furthermore, most bioassays require at least $24 \mathrm{~h}$ to complete. Finally, the cell line can change its responsiveness to cytokine over time.

\section{Immunoassays}

Antibody-based assays [ELISA and radioimmunoassay (RIA)] sold as kits are currently the standard for quantification of most cytokines, but the long assay time hinders their utility in the clinical setting. Recent developments in microfluorimetry and microfluidics have permitted the simultaneous detection of multiple analytes using anti- body-based capture and reporter molecules (40). Although this approach has shortened the assay development time, it is still too long to provide widespread benefit in the diagnosis and treatment of infections in the acute care setting.

Conventional antibodies. The rapidity and sensitivity of antibody-based assays are limited by the affinity of the antibody for its cognate antigen, although recent advances using "singlechain Fv fragments" and the manipulation of antigen specificities by molecular techniques may be helpful in addressing these problems $(7,13,24,27$, 29,56,58). Antibody-based assays still have a number of drawbacks. Currently, the production of specific anti-cytokine antibodies is expensive because of the requirement for animals or tissue culture to produce these molecules; production runs suffer from batch-tobatch variation; and the initial product is contaminated with naturally occurring antibodies that require absorption to render the reagents specific. These conditions apply to both monoclonal and polyclonal antibodies irrespective of whether they are generated in vivo in animals or in vitro in bioreactors.

While specific antibodies for cytokines are expensive to produce, they still provide an advantage for quantification over labor-intensive cellular bioassays. Immunoassays have equal sensitivity $(\mathrm{pg} / \mathrm{mL})$, are faster and less expensive to perform, and require less specialized equipment and personnel. Despite these advantages, recent international collaborative studies by the World Health Organization (WHO) and others have shown that current ELISA and RIA assays for tumor necrosis factor (TNF)- $\alpha$, interleukin (IL)-2, and IL6 lacked the desired accuracy and reproducibility $(15,31)$. These studies noted differences, often exceeding 100fold, between cytokine levels measured by different immunoassay procedures for the same sample $(15,31)$. Another study using an IL-1 ELISA demonstrated that over $90 \%$ of the samples testing positive $(>100 \mathrm{pg} / \mathrm{mL})$ were false when tested by bioassay (22).

False positives were measured also in samples sent to a reference laboratory for analysis. The false-positive reaction was blocked by the addition of normal mouse serum to the test samples, indicating the presence of human antimouse IgG heterophilic antibodies reacting with the immobilized mouse anti-cytokine antibody (22). Also, both $\alpha-2$ macroglobulin and albumin have been shown to exhibit profound effects on the measurement of cytokine levels by commercial ELISA kits for IL- $\beta$, IL2 , IL-4, IL-6, and TNF- $\alpha$ (25). The effects of these and other potentially interfering plasma proteins may vary with kits from different suppliers and could account for some or all of the problems identified in the WHO studies. Because all of these kits use antibodies that differ 
significantly in affinity and specificity between lots and suppliers, they will continue to suffer from inconsistencies in assay accuracy that are due to their primary detection reagents.

The problems associated with anti- body-based cytokine quantitation assays were reminiscent of the initial problems that were encountered in screening monoclonal antibodies using rabbit antimouse immunoglobulin reagents. In the mouse monoclonal antibody system, the

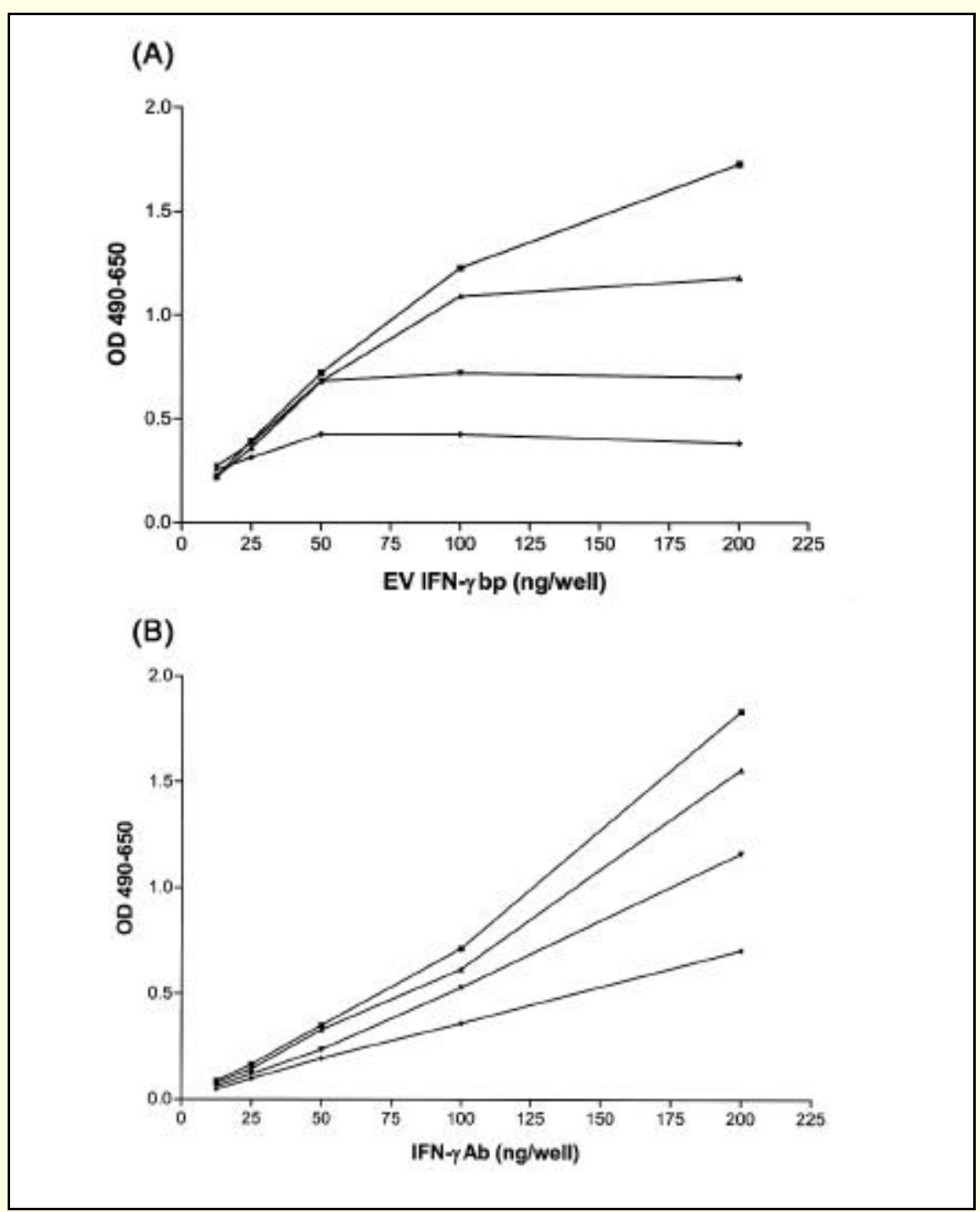

Figure 1. Checkerboard analysis of biotinylated mouse IFN- $\gamma$ binding to immobilized IFN- $\gamma$ binding protein or polyclonal goat anti-mouse IFN- $\gamma$ antibody. (A) IFN- $\gamma$ binding protein. The indicated amounts of IFN- $\gamma$ binding protein in $50 \mu \mathrm{L}$ PBS at $\mathrm{pH} 7.4$ were adsorbed overnight at $4^{\circ} \mathrm{C}$ to wells of an Immulon ${ }^{\circledR}$ II microplate (Dynatech Laboratories, Chantilly, VA, USA). The wells were washed three times with $0.2 \mathrm{~mL}$ PBS and $0.1 \%$ Tween ${ }^{\circledR} 20$, followed by blocking for $1 \mathrm{~h}$ with $0.1 \mathrm{~mL} 0.1 \%$ gelatin (Sigma, St. Louis, MO, USA) and incubation for $0.5 \mathrm{~h}$ at room temperature with biotinylated mouse IFN$\gamma$ in $0.1 \mathrm{~mL}$ PBS and $0.1 \%$ gelatin. Following washes, a 1:5000 dilution of streptavidin-HRP (Kirkegaard $\&$ Perry Laboratories, Gaithersburg, MD, USA) was added for $0.5 \mathrm{~h}$ at room temperature. Washed wells were then incubated with o-phenylenediamine substrate (Sigma) for $15 \mathrm{~min}$, followed by measurement of color development at 490-650 nm in a Biokinetics model EL-340 microplate reader (Bio-Tek Instruments, Winooski, VT, USA). Control wells contained $50 \mathrm{ng}$ immobilized gelatin, and the background absorbance values were usually less than $0.15 \mathrm{OD}$. All assays were carried out in triplicate, and the variation observed was less than $10 \%$ of the mean. Biotinylated mouse IFN- $\gamma(\mathrm{ng} /$ well): $6.3(\boldsymbol{\square}), 3.1(\boldsymbol{\Delta}), 1.6$ $(\nabla)$, and $0.8(\diamond)$. (B) Polyclonal goat anti-mouse IFN- $\gamma$ antibody. The assay was carried out as described in part A, except increasing amounts of polyclonal goat anti-mouse IFN- $\gamma$ neutralizing antibody were im mobilized on the well surfaces instead of the IFN- $\gamma$ binding protein. Biotinylated mouse IFN- $\gamma$ (ng/well): $6.3(\mathbf{\square}), 3.1(\mathbf{\Delta}), 1.6(\boldsymbol{\nabla})$, and $0.8(\bullet)$.

ability to distinguish between positive and negative hybridoma supernatants in screening assays proved difficult, and the results were not always reproducible from day to day. These technical limitations were overcome with the introduction of protein A, a high-affinity bacterial immunoglobulin-binding protein that has the ability to bind to the Fc region of many species and subclasses of mam malian IgG immunoglobulins (11). The availability of protein A proved to be critical for the early development of screening methods to identify monoclonal antibody-producing hybridomas; however, studies indicated that protein A was not ideal since it failed to react with all isotypes and subclasses of mouse immunoglobulin (11). Subsequent studies led to the identification of a second generation of bacterial IgGbinding proteins, like streptococcal protein $\mathrm{G}(42,43)$, that could extend the range of reactive monoclonal antibodies that could be identified. These reagents also prove to be of great value, once im mobilized, for the subsequent purification of monoclonal antibodies generated in vivo or in vitro $(9,10)$.

Synthetic antibodies. Synthetic antibodies were constructed through linking repertoires of antibody variable heavy and light chain domains. These single-chain $\mathrm{Fv}$ fragments were expressed as fusions with a bacterial phage coat protein, permitting the display of a library of single-chain Fv fragments on the surface of phage as well as the isolation of defined binding activities and the genes responsible (57). Using this approach, phage repertoires were constructed that contain $10^{7}$ to greater than $10^{10}$ phage clones and were used to isolate single-chain Fv fragments against a variety of antigens. The initial binding affinities of these single-chain $\mathrm{Fv}$ fragments were only moderate $\left(10^{5}-10^{6} \mathrm{M}^{-1}\right)$ but in certain cases could be increased to nanomolar and even picomolar levels through targeted mutagenesis. Because the singlechain $\mathrm{Fv}$ fragments are produced in bacterial expression systems, they will be less costly to produce and purify than conventional antibodies. Thus, single-chain Fv fragments with affinities in the nanomolar range and high specificity for the target antigen are an alternative to polyclonal and monoclonal 
antibodies as reagents for the development of immunoassays for cytokines.

The ability to produce antibody-like molecules in E. coli using phage display technology and to humanize the constant regions has made enormous technical advances within the past five years $(13,33,58)$. The potential to design and manipulate the affinity of these reagents for any novel specificity (e.g., a unique tumor specific antigen) and to produce the products in a well-

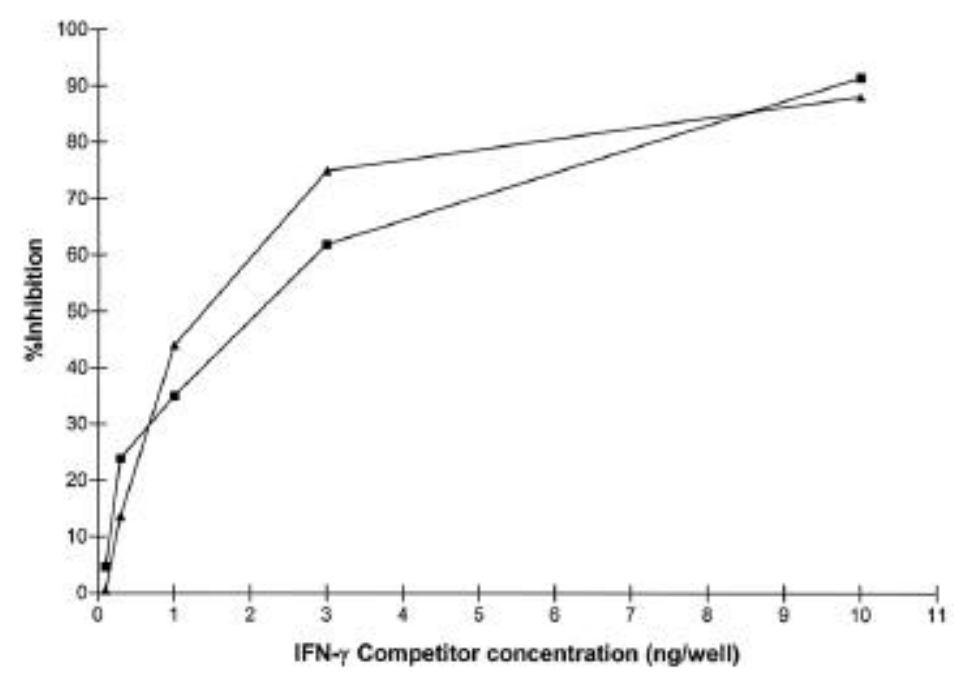

Figure 2. Human and mouse IFN- $\gamma$ dose-dependent inhibition of biotinylated mouse IFN- $\gamma$ binding to immobilized IFN- $\gamma$ binding protein. The assay was carried out as described in the legend to Figure 1 , except each well was coated with $75 \mathrm{ng}$ IFN- $\gamma$ binding protein, and $3.2 \mathrm{ng}$ biotinylated mouse IFN- $\gamma$ were mixed with increasing amounts of human IFN- $\gamma(\boldsymbol{\Delta})$ or mouse IFN- $\gamma(\boldsymbol{\square})$. The percent inhibition was calculated by dividing the OD obtained with the various competitors by the OD in the absence of competitor times 100 .

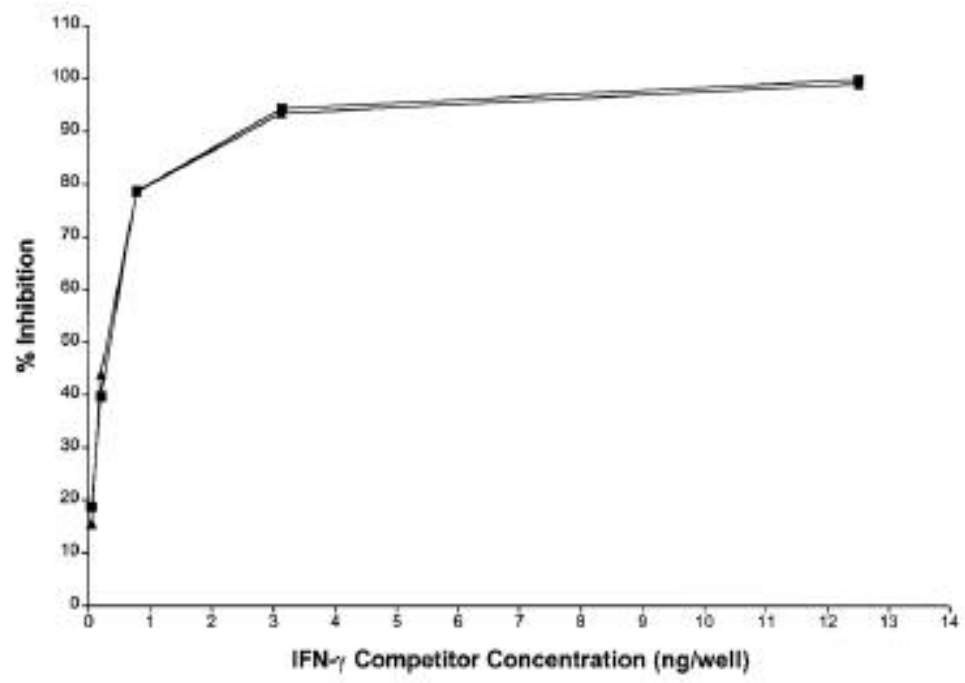

Figure 3. The specificity of the IFN- $\gamma$ binding protein-based immunoassay. The assay was carried out as described in the legend to Figure 1, except each well was coated with $75 \mathrm{ng}$ IFN- $\gamma$ binding protein, and $3.2 \mathrm{ng}$ biotinylated mouse IFN- $\gamma$ were mixed with $0.1 \mathrm{~mL}$ of either PBS and $0.1 \%$ gelatin and $0.1 \%$ Tween 20 (PBST) (ם) or a 1/10 dilution of human pooled plasma in PBST ( $\mathbf{\Delta})$. Each buffer condition was supplemented with increasing amounts of mouse IFN- $\gamma$.

controlled fermentation system offers great promise for therapeutics and diagnostics in a variety of human diseases $(7,29,38,56)$. The capability to produce these key reagents without the use of an animal intermediate has great practical value in addressing the issue of batch-to-batch variability and cost.

The very precise epitope recognition by antibodies is, however, a basis for limiting their use for diagnostic applications involving large outbred populations with minor allelic polymorphisms in the target protein. As noted earlier in the WHO tests, the existing panel of cytokine-specific monoclonal antibodies has not performed with the precision and reproducibility required in routine clinical diagnostic assays (15,31). These findings are reminiscent of other studies using monoclonal antibodies to human IgG subclasses, which demonstrated similar problems in another WHO-organized comparative study (26). In this case, some of the problems could be mapped to differences in allotypes of immunoglobulins. This precise specificity was also observed with certain bacterial immunoglobulin-binding proteins (20); however, some sources of bacterial IgG-binding proteins demonstrate pan-selectivity for all allotypes of given human IgG subclasses tested (28).

Thus, while antibody reagents generated by a combination of phage display technology, the use of mutagenesis strategies for affinity maturation, and expression in vitro are all practical, the specificity of the resulting reagent may be too narrow to act effectively as cytokine binding reagents across diverse human populations.

\section{SPECIFIC PATHOGEN-ENCODED CAPTURE/TARGETED RECEP- TOR ACTIVITIES (SPECTRA) AS ANTIBODY MIMICS}

Many pathogens have been reported to encode high-affinity binding proteins for cytokines and other key signaling molecules of the host innate and acquired immune system. These molecules are presumably the result of a continuing evolution of the interaction between the host defenses of animals and the virulence strategies of pathogens. Thus, within the genomes of 
Table 2. Virus-Encoded Cytokine/Chemokine-Binding Proteins

\begin{tabular}{|c|c|c|c|c|}
\hline Virus & Gene & Ligand & $K_{d}(n M)$ & Reference \\
\hline Myxoma virusa (cowpox virus) & $\mathrm{T} 2$ & TNF- $\alpha$, TNF- $\beta$ & 0.2 & $23,45,47$, and 54 \\
\hline Cowpox virusa & Crm-C & TNF- $\alpha$ & 0.2 & 48 \\
\hline Cowpox virusa (ectromelia virus) & Crm-D & TNF- $\alpha$, TNF- $\beta$ & $?$ & 12 and 34 \\
\hline $\begin{array}{l}\text { Vaccinia virusa } \\
\text { (cowpox and ectromelia viruses) }\end{array}$ & B15R & $\mathrm{IL}-1 \beta$ & $0.1-0.2$ & 3 and 50 \\
\hline Tanapox virusa & $?$ & IL-2/IL-5/IFN- $\gamma$ & $?$ & 17 \\
\hline $\begin{array}{l}\text { Molluscum contagiosum virusa } \\
\text { (ectromelia, cowpox, swinepox, } \\
\text { variola, and vaccinia viruses) }\end{array}$ & MC54L & IL-18 & $2-10.0$ & $2,8,39,59$, and 60 \\
\hline $\begin{array}{l}\text { Myxoma virusa (ectromelia, cowpox, } \\
\text { variola, and vaccinia viruses) }\end{array}$ & T7 & IFN- $\gamma$ (type II IFN) & 1.2 & $4,35-37$, and 55 \\
\hline $\begin{array}{l}\text { Vaccinia virusa (ectromelia, variola, } \\
\text { myxoma, and cowpox viruses) }\end{array}$ & B18R & IFN- $\alpha / \beta$ (type I IFN) & $0.2-0.4$ & 14,32 , and 53 \\
\hline Epstein-Barr virusb & BARF1 & CSF-1 & $?$ & 51 \\
\hline Orf virusa & GIF & GM-CSF, IL-2 & $0.4-1.0$ & 16 \\
\hline $\begin{array}{l}\text { Herpesvirus saimirib,c (human } \\
\text { herpesvirus 8) }\end{array}$ & ECRF3 & $\alpha \gg>\beta$ chemokines & $25-520$ & $1,6,21$, and 38 \\
\hline Human cytomegalovirusb,c & US28 & $\beta$ chemokines & $0.3-0.6$ & 18,30 , and 52 \\
\hline $\begin{array}{l}\text { Cowpox virusa (rabbitpox, variola, } \\
\text { ectromelia, and vaccinia viruses) }\end{array}$ & $\mathrm{T} 1 / 35 \mathrm{kD}$ & $\beta \gg>\alpha$ chemokines & $0.04-0.09$ & 5,19, and 49 \\
\hline
\end{tabular}

pathogens, we could expect to find the coding sequences for binding proteins, mediators, and/or mimics that disrupt the normal regulation and/or activity of the most critical pathways of the acquired or innate immune responses.

In the context of SPECTRA, the genomes of pathogens would be analogous to the immune splenocytes used to generate monoclonal antibodies. For example, to isolate a binding protein for IL-12, extracts of wild-type pathogens or a library of genes prepared from chromosomal DNA of pathogens would be screened for activities that interfere in an IL-12 immunoassay, bioassay, or binding assay. A positive result would indicate the potential presence of the desired binding activity encoded within the chromosomal DNA of the tested pathogen. This step is equivalent to the initial screening step in a hybridoma fusion, which is followed by an analogous cloning step to identify a hybridoma clone (i.e., identifying the gene expressing the desired activity).

In the SPECTRA screening strategy, the colony expressing a gene encoding the desired activity would be identified

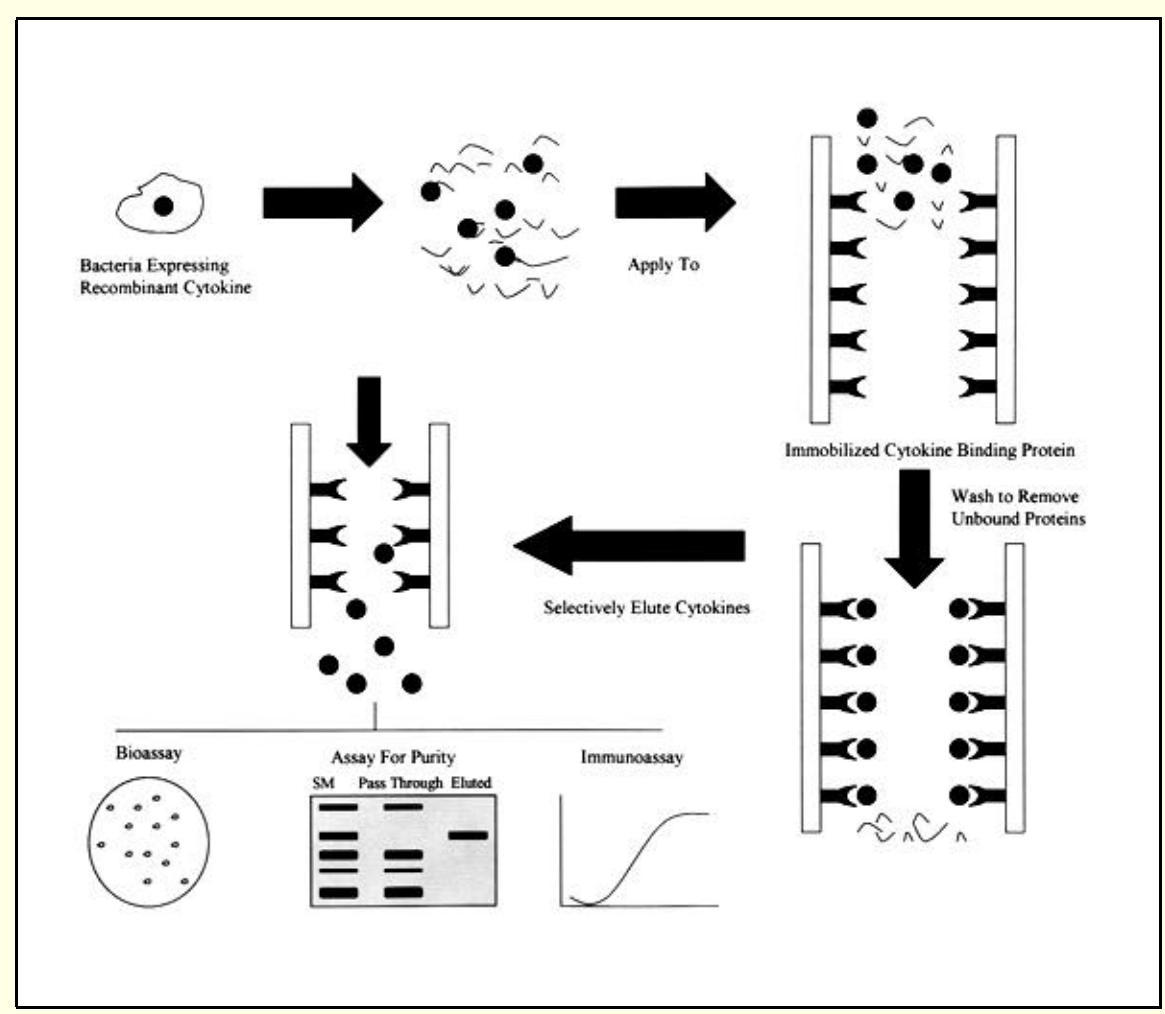

Figure 4. Schematic representation of affinity purification strategy utilizing immobilized cytokinebinding proteins. 
and characterized. Standard screening assays to identify a specific functional gene product are common in combinational chemistry, phage display, and monoclonal antibody technology. Once a positive clone is identified, it is then a relatively simple matter to obtain the gene sequence and express large quantities of the product using standard genetic engineering strategies. If a functional recombinant protein can be expressed that retains the desired specificity, then it is practical to develop a range of assays and purification procedures based on the protein's binding characteristics.

The ability to manipulate the sequence to increase or decrease affinity for a given application is also practical. Like antibodies, pathogen-binding protein genes can be manipulated to increase binding affinity by random or targeted mutagenesis and selection for products with higher affinity. This procedure would be equivalent to affinity maturation that is associated with somatic mutations in B cells. Also, through genetic engineering strategies, active domains can be identified and duplicated to potentially increase affinity and/or to remove undesirable crossreactivities. This approach is well established for the streptococcal IgGbinding molecule, protein $\mathrm{G}$ (41).

Based on the parallels with protein A and protein $G$, we decided to evaluate pathogen-encoded cytokine-binding proteins as an alternative method to quantify cytokines. The rationale was that high-affinity viral cytokine-binding proteins could be used in place of a specific antibody in capture-based immunoassay formats (i.e., act in an analogous manner to the second antibody role fulfilled by protein A or protein $G$ in monoclonal antibody screening).

Table 2 summarizes the known virus-encoded cytokine-binding proteins. It is of interest to note that as a genus the orthopoxviruses encode at least three distinct TNF-binding proteins as well as binding proteins for chemokines, IL-18, IL-1 $\beta$, and interferons (IFNs). The proteins are secretory homologs of cellular receptors and cytokine-binding proteins that block cytokine action extracellularly before receptor engagement. One of the important features of a number of the binding proteins is their ability to bind cytokines (i.e., IL-18, TNF, IFN- $\gamma$, and chemokines) from closely related species. This suggests that the viral binding proteins are recognizing a general molecular shape of the target ligand. In the development of cytokine assays, this "plastic" specificity is a major advantage over monoclonal antibodies or singlechain Fv fragments whose affinity for ligand can be affected by intra- or interspecies genetic polymorphisms.

Each of these viral binding proteins has potential for the measurement of its cognate ligand. IL-1 $\beta$ and TNF are im portant mediators of septic shock, and the IFNs can be important indicators of the progression or recovery from diseases and are used therapeutically as well. The availability of sensitive, rapid assays for these molecules would be beneficial. Importantly, the extremely high affinity of the viral cytokine-binding proteins for their ligands suggests that their use as capture and/or detection reagents in immunoassays may result in improved sensitivity compared to antibody-based assays. While the potential for the use of pathogen-binding proteins as antibody mimics is theoretically practical, to date there have been no published examples of their use for quantitative assays. To ensure that these reagents can be of utility in immunoassay-like formats, we evaluated the ability of a poxvirus IFN- $\gamma$ binding protein to act as a capture reagent in an assay to measure both human and mouse IFN- $\gamma$.

\section{Measurement of IFN- $\gamma$ by an Assay Based on a Pathogen-Encoded Binding Protein}

An IFN- $\gamma$ binding protein is found in a range of poxviruses and is probably the best-studied cytokine-binding protein $(4,35-37,55)$. For this reason and the fact that IFN- $\gamma$ is a prototypic Th1 cytokine whose plasma levels are predictive of a number of disease states (44), this protein would be a good candidate as the selective binding reagent for measuring IFN- $\gamma$ in clinical samples.

To evaluate the use of the viral IFN $\gamma$ binding protein in place of an anti-IFN $\gamma$ antibody in immunoassays, increasing concentrations of the binding protein were immobilized onto wells of a microplate. Increasing concentrations of a biotinylated preparation of mouse IFN- $\gamma$ 
Table 3. Comparison of Potential Cytokine Capture Reagents

\begin{tabular}{|c|c|c|c|c|}
\hline Considerations & $\begin{array}{l}\text { Polyclonal } \\
\text { Antibodies }\end{array}$ & $\begin{array}{l}\text { Monoclonal } \\
\text { Antibodies }\end{array}$ & $\begin{array}{l}\text { Engineered } \\
\text { Antibodies }\end{array}$ & $\begin{array}{l}\text { Pathogen-Binding } \\
\text { Proteins }\end{array}$ \\
\hline Cytokine selectivity & $\begin{array}{l}\text { Potential problems with } \\
\text { cross-reactivity }\end{array}$ & $\begin{array}{l}\text { Potential problems with } \\
\text { minor polymorphic variants }\end{array}$ & $\begin{array}{l}\text { Potential problems with } \\
\text { minor polymorphic variants }\end{array}$ & $\begin{array}{l}\text { General pan-specific } \\
\text { binding }\end{array}$ \\
\hline Affinity & $10^{-6}-10^{-8} \mathrm{M}$ & $10^{-6}-10^{-8} \mathrm{M}$ & $10^{-6}-10^{-10 M}$ & $10^{-6}-10^{-10 M}$ \\
\hline $\begin{array}{l}\text { Batch-to-batch } \\
\text { variation }\end{array}$ & $\begin{array}{l}\text { Biological variation in } \\
\text { antibody preparations }\end{array}$ & Reproducible & Reproducible & Reproducible \\
\hline $\begin{array}{l}\text { Identification of } \\
\text { suitable candidate } \\
\text { reagent }\end{array}$ & $\begin{array}{l}\text { Directed by vaccination } \\
\text { and selective antigen- } \\
\text { specific screening }\end{array}$ & $\begin{array}{l}\text { Selected by immunization } \\
\text { and selective screening }\end{array}$ & $\begin{array}{l}\text { Adapted from suitable } \\
\text { monoclonal or phage library }\end{array}$ & $\begin{array}{l}\text { Detected in prior } \\
\text { studies (see Table 1) }\end{array}$ \\
\hline Stability on storage & Good & $\begin{array}{l}\text { Some problems noted with } \\
\text { certain hybridoma clones }\end{array}$ & Good & Good \\
\hline Preparation & $\begin{array}{l}\text { Purified immunogen } \\
\text { and goats or rabbits } \\
\text { for immunization }\end{array}$ & $\begin{array}{l}\text { Purified immunogen and } \\
\text { mice and/or bioreactor } \\
\text { requirement once suitable } \\
\text { hybridoma identified }\end{array}$ & Fermentor & Fermentor \\
\hline $\begin{array}{l}\text { Downstream } \\
\text { processes }\end{array}$ & $\begin{array}{l}\text { Requires antibody } \\
\text { purification and extensive } \\
\text { absorption for specificity }\end{array}$ & $\begin{array}{l}\text { Antibody purification } \\
\text { normally monospecific } \\
\text { thereafter }\end{array}$ & $\begin{array}{l}\text { Straightforward protein } \\
\text { purification; Some } \\
\text { concerns for appropriate } \\
\text { folding for functionality }\end{array}$ & $\begin{array}{l}\text { Straightforward protein } \\
\text { purification; Minimal } \\
\text { concerns for } \\
\text { appropriate folding }\end{array}$ \\
\hline Animal requirements & Yes & Yes & No & No \\
\hline $\begin{array}{l}\text { Time required to } \\
\text { prepare reagent }\end{array}$ & 2-4 months & $2-4$ weeks & $3-5$ days & $3-5$ days \\
\hline Batch size & $\begin{array}{l}\text { Limited by } \\
\text { animal facilities }\end{array}$ & $\begin{array}{l}\text { Limited by animal facilities } \\
\text { or bioreactor capacity }\end{array}$ & $\begin{array}{l}\text { Limited by fermentor } \\
\text { capacity }\end{array}$ & $\begin{array}{l}\text { Limited by fermentor } \\
\text { capacity }\end{array}$ \\
\hline $\begin{array}{l}\text { Expected cost of } \\
\text { production }\end{array}$ & High & High & Low & Low \\
\hline
\end{tabular}

was added to each well in a checkerboard manner, and bound mouse IFN- $\gamma$ was detected using a streptavidin-enzyme conjugate reporter system. Figure 1 presents the results of a representative experiment using this checkerboard strategy. This experiment demonstrates that the IFN $\gamma$ binding protein can act as a capture reagent for fluid phase mouse IFN- $\gamma$ and that saturable binding can be achieved. When a similar series of studies were carried out using human IFN- $\gamma$, a similar pattern of reactivity was observed (data not shown).

To compare the efficiency of the viral IFN- $\gamma$ binding protein with the currently used capture reagent, an antibody specific for mouse IFN- $\gamma$, a similar experiment was performed using a commercially available goat polyclonal anti-mouse IFN- $\gamma$ neutralizing antibody as the capture reagent. The antibody was immobilized onto a microplate at varying concentrations, and binding of biotinylated mouse IFN- $\gamma$ was measured. The results presented in
Figure 1B showed binding of the tracer under the identical experimental conditions used to generate the data for the IFN- $\gamma$ binding protein shown in Figure 1A. A comparison of the results in Figure $1, \mathrm{~A}$ and $\mathrm{B}$, shows the antibody capture reagent did not result in saturable binding, while this could be achieved using the viral binding protein.

In the next series of studies, the ability of unlabeled mouse or human IFN- $\gamma$ to compete for binding of biotinylated IFN- $\gamma$ was tested in an ELISA format using the viral IFN- $\gamma$ binding protein as the capture reagent. Fluid-phase IFN- $\gamma$ from either human or mouse caused dose-dependent inhibition of binding of the mouse IFN- $\gamma$ tracer (Figure 2). These results indicate that the viral IFN- $\gamma$ binding protein can act as a highaffinity antibody mimic and that this assay system could detect fluid-phase mouse IFN- $\gamma$ in the low nanogram to high picogram range.

Since, as noted earlier, a key problem in conventional ELISA was inter- ference from major plasma proteins (e.g., albumin); these experiments were repeated using human plasma to which known quantities of human IFN- $\gamma$ were added. The results presented in Figure 3 demonstrated that the inhibition of binding of biotinylated mouse IFN- $\gamma$ tracer to the viral IFN- $\gamma$ binding protein was unaffected by the presence of human plasma. Note that the endogenous level of IFN- $\gamma$ in the pooled human plasma sample was below the level of detection in this assay (Figure 3).

Taken together, these results indicate that the viral binding protein can be im mobilized without loss of function and can act as a specific capture reagent in an ELISA. These studies support the theoretical predictions that a viral binding protein can effectively substitute for an antibody in assays to detect IFN- $\gamma$. Indeed, the higher affinity of the binding protein has the potential to increase the sensitivity and speed of assays for the inflammatory cytokine, IFN- $\gamma$.

Based on these assay studies using 
the poxvirus IFN- $\gamma$ binding protein, we would anticipate that this approach could be extrapolated to other cytokines by substitution of a binding protein with different specificity. Furthermore, the use of these selective binding molecules in other assay platforms and for other applications can be envisioned. In particular, the need for efficient methods for the purification of recombinant cytokines for use in therapeutic activities suggests that the general strategy outline in Figure 4 can be utilized to purify cytokines from complex mixtures. This general strategy could also be used to selectively precipitate cytokines from biological samples to address fundamental basic research questions of the distribution of cytokines in different secretions or extracellular fluids.

\section{RAPID CYTOKINE DETECTION ASSAYS}

There is a clear need for rapid, sensitive, and reproducible cytokine detection assays for clinical samples. Thus, an evaluation of selective capture reagents that can be used to develop such assays is warranted. Traditionally, the choice of capture reagent has focused

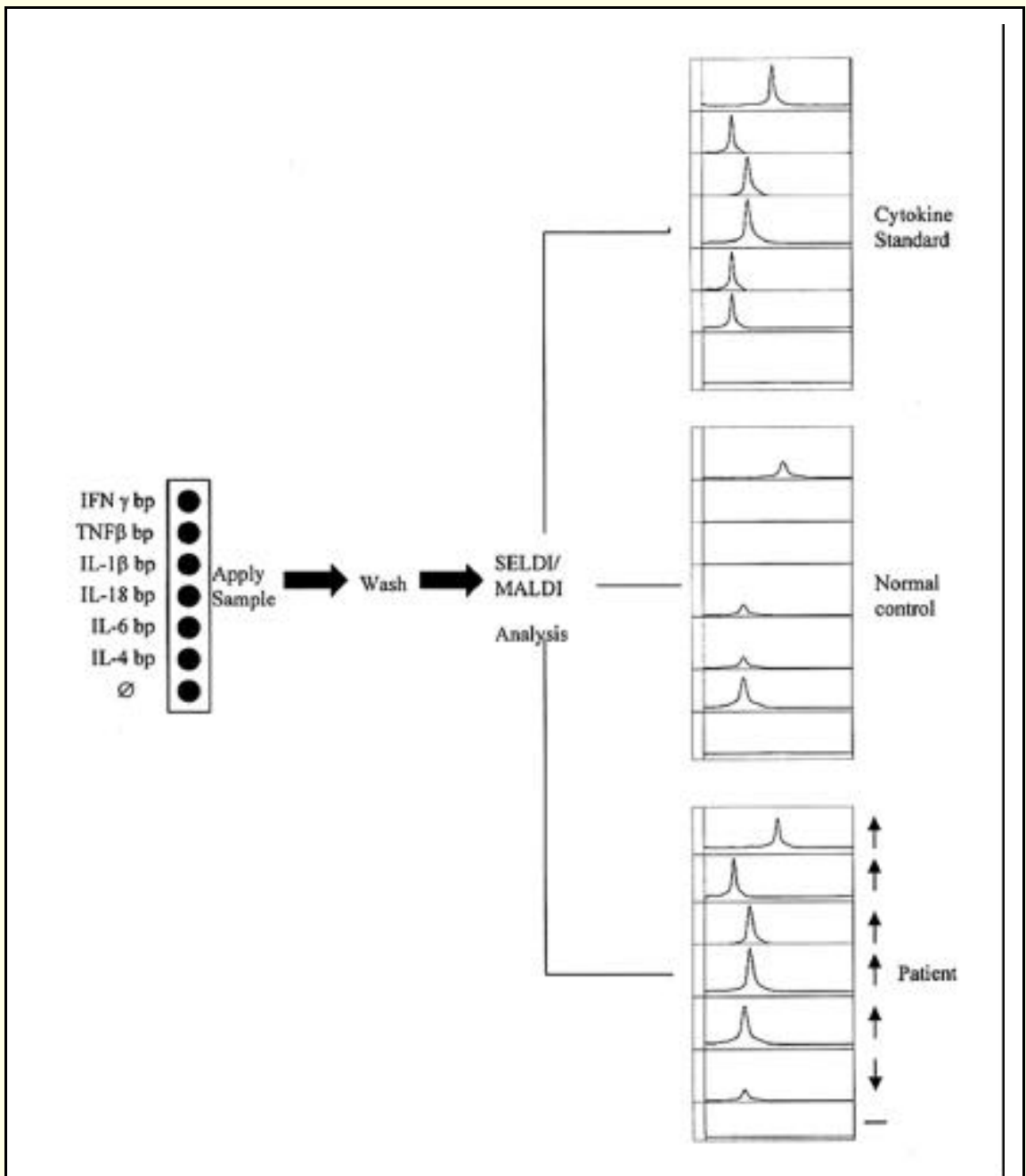

Figure 5. Schematic representation of protein chip-based profiling of cytokines using a mass spectral read out. Immobilized cytokine capture reagents [e.g., specific viral binding proteins (bp), monoclonal antibodies, single-chain antibodies, etc.] are briefly incubated with a patient specimen, washed with deionized water, and overlaid with an energy-absorbing molecule. Each spot is then vaporized by a laser, and the bound "ligands" analyzed by time-of-flight in a matrix-assisted laser desorption/ionization-mass spectrometer instrument. The molecular weight and signal strength of the detected molecules are com pared to a series of cytokine standards. The levels of individual cytokines detected in the specimen are then scored as elevated $\uparrow$, depressed $\downarrow$, or normal —. 
on antibodies or antibody-derived molecules; however, based on the studies described above, pathogen-binding proteins with selective recognition properties for cytokines merit further consideration. The key requirement for a capture reagent is a high degree of specificity that permits rapid binding of the targeted cytokine and a slow off-rate of bound cytokine and specific binding of polymorphic variants. Table 3 sum marizes the general characteristics of different classes of currently available cytokine capture reagents. A comparison of the properties of these reagents indicates that the pathogen binding proteins merit further evaluation as a new class of specific binding reagents for rapid cytokine assay development.

\section{FUTURE DIRECTIONS}

The value of cytokine profiling in diagnosing and monitoring disease progression is now beginning to be elucidated from basic studies in both mouse models and human clinical research protocols. It is clear that in disease states cytokine profiles are dynamic in both quantity and complexity of the signaling molecules. This necessitates that rapid assays for detection of cytokines in conditions like septic shock be available to help the physician im plement the appropriate treatment protocol. Furthermore, given the cascade nature of cytokine responses, the ability to monitor rapidly ( $<45 \mathrm{~min}$ ) the actual cytokine profile for patients undergoing cytokine therapy, for such conditions as cancer or autoimmunity, will be essential to minimize toxic effects and maximize therapeutic benefit. Consequently, rapid assays that can provide cytokine profiles and at least semi-quantitative data will be extremely beneficial.

The existence of naturally occurring surrogate antibodies or binding proteins encoded within a variety of different viral genomes offer high affinity and selective binding properties that are not as sensitive to polymorphic variations in cytokines and other signaling molecules that are present in outbred populations. The analysis of the structures of known cytokine-binding proteins and other SPECTRA among bacteria, viruses, and fungi combined with data-mining strategies of pathogenic genomes is likely to provide a plethora of useful reagents for monitoring immune mediators. These binding domains could also be exploited in existing antibody framework constructs and be further engineered for enhanced or decreased affinity depending on the desired application.

These pathogen-encoded capture reagents are expected to find applications in combination with other evolving proteomic technologies. For example, viral cytokine-binding proteins bound to protein chips and analysis using a mass spectral read out [MALDI or surface-enhanced laser desorption ionization-time of flight (SELDI-TOF)] (Figure 5) are one anticipated development that will facilitate both a high degree of sensitivity and rapid data generation. This immunoproteomic assay system also has the potential to use the mass spectral profile to monitor the quantity of cytokine present and the conversion of pro-cytokines to their biologically active form, and potentially monitor cytokine fragments that could be used to follow biological regulation of these molecules in vivo.

\section{ACKNOWLEDGMENTS}

The authors would like to thank Dr. Rob Christner of ReceptorPro, Inc. (Ann Arbor, MI, USA) for purifying the IFN- $\gamma$ binding protein and preparing the biotinylated tracer. This work was supported in part by National Institutes of Health Small Business Technology Transfer grant no. 1R41AI/CA42431-01 to ReceptorPro, Inc. Drs. Boyle and Buller have a significant financial interest in ReceptorPro, Inc. and act as consultants to the company.

\section{REFERENCES}

1.Ahuja, S.K. and P.M. Murphy. 1993. Molecular piracy of mammalian interleukin-8 receptor type B by herpesvirus saimiri. J. Biol. Chem. 268:20691-20694.

2.Alcami, A., N.A. Bryant, and V.P. Smith. 2000. Ectromelia, vaccinia and cowpox viruses encode secreted interleukin-18-binding proteins. J. Gen. Virol. 81:1223-1230.

3.Alcami, A. and G.L. Smith. 1992. A soluble receptor for interleukin- $1 \beta$ encoded by vaccinia virus: a novel mechanism of virus modulation of the host response to infection. Cell 71:153167.

4.Alcami, A. and G.L. Smith. 1995. Vaccinia, cowpox and camelpox viruses encode soluble gamma interferon receptors with novel broad species specificity. J. Virol. 69:4633-4639.

5.Alcami, A., J.A. Symons, P.D. Collins, T.J. Williams, and G.L. Smith. 1998. Blockade of chemokine activity by a soluble chemokine binding protein from vaccinia rirus. J. Im munol. 160:624-633.

6.Arvanitakis, L., E. Geras-Raaka, A. Varma, M.C. Gershengorn, and E. Cesarman. 1997. Human herpesvirus KSHV encodes a constitutively active G-protein-coupled receptor linked to cell proliferation. Nature 385:347-350.

7.Babcook, J.S., K.B. Leslie, O.A. Olsen, R.A. Salmon, and J.W. Schrader. 1996. A novel strategy for generating monoclonal antibodies from single, isolated lymphocytes producing antibodies of defined specificities. Proc. Natl. Acad. Sci. USA 93:7843-7848.

8.Born, T.L., L.A. Morrison, D.J. Esteban, N. Chen, L.G. Thebeau, N. Chen, M.K. Spriggs, J.E. Sims, and R.M.L. Buller. 2000. A poxvirus protein that binds to and inactivates IL-18, and inhibits NK cell response. J. Im munol. 164:3246-3254.

9.Boyle, M.D.P., E.L. Faulmann, and D.W. Metzger. 1993. Applications of bacterial im munoglobulin-binding proteins to the purification of immunoglobulins, p. 91-112. In T.T. Ngo (Ed.), Molecular Interactions and Bioseparation. Plenum Press, New York.

10.Boyle, M.D.P. and D.W. Metzger. 1994. Antibody binding bacterial proteins as immunoreagents, p. 177-209. In E.P. Lillehoj and V.S. Malik (Eds.), Antibody Techniques: A Guide for Non-Immunologists. Academic Press, New York.

11.Boyle, M.D.P. (Ed.) 1990. Bacterial Im munoglobulin Binding Proteins. Applications in Immunotechnology. Academic Press, New York.

12.Chen, N., R.M.L. Buller, E.M. Wall, and C. Upton. 2000. Analysis of host response modifier ORFs of ectromelia virus, the causative agent of mousepox. Virus Res. 66:155-173.

13.Chiswell, D.J. and J. McCafferty. 1992. Phage antibodies: will new 'coliclonal' antibodies replace monoclonal antibodies? Tibtech 10:80-84.

14.Colamonici, O.R., P. Domanski, S.M. Sweitzer, A. Larner, and R.M.L. Buller. 1995. Vaccinia virus B18R gene encodes a type I interferon-binding protein that blocks interferon $\alpha$ transmembrane signaling. J. Biol. Chem. 270:15974-15978.

15.de Kossodo, S., V. Houba, and G.E. Grau. 1995. Assaying tumor necrosis factor concentrations in human serum. A WHO international collaborative study. J. Immunol. Methods 182:107-114.

16.Dean, D., J. McInnes, A. Percival, A. Wood, J. Thomson, A. Lear, J. Gilray, S. Fleming, A. Mercer, and D. Haig. 2000. Orf virus encodes a novel secreted protein inhibitor of granuloyte-macrophage colony-stimulating factor and interleukin-2. J. Virol. 74:1313-1320.

17.Essani, K., S. Chalasani, R. Eversole, L. Beuving, and L. Birmingham. 1994. Multiple anti-cytokine activities secreted from tanapox virus-infected cells. Microb. Path. 17:347-353.

18.Gao, J.-L. and P.M. Murphy. 1994. Human cytomegalovirus open reading frame US28 en- 
codes a functional $\beta$ chemokine receptor. J. Biol. Chem. 269:28539-28542.

19.Graham, K.A., A.S. Lalani, J.L. Macen, T.L. Ness, M. Barry, L.Y. Liu, A. Lucas, I. ClarkLewis et al. 1997. The T1/35kDa family of poxvirus-secreted proteins bind chemokines and modulate leukocyte influx into virus-infected tissues. Virology 229:12-24.

20.Gronenborn, A.M. and G.M. Clore. 1993. Identification of the contact surface of a streptococcal protein $\mathrm{G}$ domain complexed with a human Fc fragment. J. Mol. Biol. 233:331-355.

21.Guo, H.-G., P. Browning, J. Nicholas, G.S. Hayward, E. Tschlachler, Y.-W. Jiang, M. Sadowska, M. Raffeld et al. 1997. Characterization of a chemokine receptor-related gene in human herpesvirus 8 and its expression in $\mathrm{Ka}$ posi's sarcoma. Virology 228:371-378.

22.Herzyk, D.J. and M.D. Wewers. 1993. ELISA detection of IL-1 $\beta$ in human sera needs independent confirmation: false positives in hospitalized patients. Am. Rev. Resp. Dis. 147:139142.

23.Hu, F.-Q., C.A. Smith, and D.J. Pickup. 1994. Cowpox virus contains two copies of an early gene encoding a soluble secreted form of the type II TNF receptor. Virology 204:343-356.

24.Jakobovits, A. 1995. Production of fully human antibodies by transgenic mice. Curr. Opin. Biotechnol. 6:561-566.

25.James, K., I. Milne, A. Cunningham, and S.F. Elliot. 1994. The effect of $\alpha_{2}$ macroglobulin in commercial cytokine assays. J. Immunol. Methods 168:33-37.

26.Jefferis, E.R. and C.B.S.F. Reimer. 1992. Evaluation of moncolonal antibodies having specificity for human IgG subclasses: results of the second IUIS/WHO study. Immunol. Lett. 31:143-168.

27.Jespers, L.S., A. Roberts, S.M. Mahler, G. Winter, and H.R. Hoogenboom. 1994. Guiding the selection of human antibodies from phage display repertoires to a single epitope of an antigen. Biotechnology 12:899-903.

28.Johansson, P.J.H., C.C. Malone, and R.C. Williams. 1994. Streptococcus pyogenes type M12 protein shows selective binding to some human immunoglobulin G3 myeloma proteins. Infect. Immun. 62:3559-3563.

29.Jolliffe, L. 1993. Humanized antibodies: enhancing therapeutic utility through antibody engineering. Intern. Rev. Immunol. 10:241-250.

30.Kuhn, D.E., C.J. Beall, and P.E. Kolattukudy. 1995. The cytomegalovirus US28 protein binds multiple CC chemokines with high affinity. Biochem. Biophys. Res. Commun. 211:325-330.

31.Langone, J.J. 1982. Protein A of Staphylococcus aureus and related immunoglobulin receptors produced by streptococci and pneumonococci. Adv. Immunol. 32:157-252.

32.Liptáková, H., G.L. Smith, A. Alcami, G.L. Smith, and P. Kontsek. 1997. Analysis of an interaction between the soluble vaccinia viruscoded type I interferon (IFN)-receptor and human IFN- $\alpha 1$ and IFN- $\alpha 2$. Virology 232:86-90.

33.Little, M., F. Breitling, S. Dubel, P. Fuchs, and M. Braunagel. 1995. Human antibody libraries in Escherichia coli. J. Biotechnol 41:187-195.

34.Loparev, V.N., J.M. Parsons, J.C. Knight, J. Fanelli Panus, C.A. Ray, R.M. Buller, D.J.
Pickup, and J.J. Esposito. 1998. A third distinct tumor necrosis factor receptor of orthopoxviruses. Proc. Natl. Acad. Sci. USA 95:3786-3789.

35.Mossman, K., R.M.L. Buller, and G. McFadden. 1995. Species specificity of ectromelia virus and vaccinia virus interferon-gamma binding proteins. Virology 208:762-769.

36.Mossman, K., P. Nation, J. Macen, M. Garbutt, A. Lucas, and G. McFadden. 1996. Myxoma virus M-T7, a secreted homolog of the interferon-gamma receptor, is a critical virulence factor for the development of myxomatosis in European rabbits. Virology 215:1730

37.Mossman, K., C. Upton, and G. McFadden. 1995. The myxoma virus soluble interferon- $\tau$ receptor homolog, M-T7, inhibits interferongamma in a species-specific manner. J. Biol. Chem. 270:3031-3038.

38.Nicholas, J., K.R. Cameron, and R.W. Honess. 1992. Herpesvirus saimiri encodes homologues of $\mathrm{G}$ protein-coupled receptors and cyclins. Nature 355:362-365.

39. Novick, D., S. Kim, G. Fantuzzi, L. Reznikov, C.A. Dinarello, and M. Rubinstein. 1999. Interleukin-18 binding protein: a novel modulator of the Th1 cytokine response. Immunity $10: 136$.

40.Oliver, K.G., J. Kettman, and R.J. Fulton. 1998. Multiplexed analysis of human cytokines by use of the FlowMetrix system. Clin. Chem. 44:2057-2060.

41.Otten, R.A. and M.D.P. Boyle. 1991. Characterization of protein $\mathrm{G}$ expressed by human group $\mathrm{C}$ and $\mathrm{G}$ streptococci. J. Microbiol. Methods 13:185-200.

42.Reis, K.J., E.M. Ayoub, and M.D. Boyle. 1984. Streptococcal Fc receptors. I. Isolation and partial characterization of the receptor from a group C streptococcus. J. Immunol 132:3091-3097.

43.Reis, K.J., E.M. Ayoub, and M.D. Boyle. 1984. Streptococcal Fc receptors. II. Comparison of the reactivity of a receptor from a group C streptococcus with staphylococcal protein A. J. Immunol. 132:3098-3102.

44.Romagnani, S. 1994. Lymphokine production by human T cells in disease states. Annu. Rev. Immunol. 12:227-257.

45.Schreiber, M., K. Rajarathnam, and G. McFadden. 1996. Myxoma virus T2 protein, a tumor necrosis factor (TNF) receptor homolog, is secreted as a monomer and dimer that each bind rabbit TNF $\alpha$, but the dimer is a more potent TNF inhibitor. J. Biol. Chem. 271:1333313341.

46.Slus-Mire, R.A. and L. Page. 1995. Quantitative cell line based bioassays for human cytokines. J. Immunol. Methods 187:191-199.

47.Smith, C.A., T. Davis, J.M. Wignall, W.S. Din, T. Farrah, C. Upton, G. McFadden, and R.G. Goodwin. 1991. T2 open reading frame from the shope fibroma virus encodes a soluble form of the TNF receptor. Biochem. Biophys. Res. Commun. 176:335-342.

48.Smith, C.A., F.-Q. Hu, T.D. Smith, C.L Richards, P. J. Smolak, R.G. Goodwin, and D.J. Pickup. 1996. Cowpox virus genome encodes a second soluble homologue of cellular TNF receptors, distinct from $\mathrm{CrmB}$, that binds TNF but not LT $\alpha$. Virology 223:132-147.
49.Smith, C.A., T.D. Smith, P.J. Smolak, D. Friend, H.G. M. Hagen, L. Park, D.J. Pickup, D. Torrance et al. 1997. Poxvirus genomes encode a secreted, soluble protein that preferentially chemokine activity yet lacks sequence homology to known chemokine receptors. Virology 236:316-327.

50.Spriggs, M.K., D.E. Hruby, C.R. Maliszewksi, D.J. Pickup, J.E. Sims, R.M.L. Buller, and J. VanSlyke. 1992. Vaccinia and cowpox viruses encode a novel secreted interleukin-1-binding protein. Cell 71:145-152.

51.Stockbine, D., J. Cohen, T. Farrah, S.D. Lyman, A.F. Wagner, F.R. DuBose, R.I. Arimtage, and M.K. Spriggs. 1998. The EpsteinBarr virus BARF1 gene encodes a novel, soluble colony-stimulating factor-1 receptor. J. Virol. 72:4015-4021.

52.Streblow, D.N., C. Soderberg-Naucler, J. Vieira, P. Smith, E. Wakabayashi, F. Ruchti, K. Mattison, Y. Altschuler, and J.A. Nelson. 1999. The human cytomegalovirus chemokine receptor US28 mediates vascular smooth muscle cell migration. Cell 99:511-520.

53.Symons, J.A., A. Alcami, and G.L. Smith 1995. Vaccinia virus encodes a soluble type I interferon receptor of novel structure and broad species specificity. Cell $81: 551-560$

54.Upton, C., J.L. Macen, M. Schreiber, and G. McFadden. 1991. Myxoma virus expresses a secreted protein with homology to the tumor necrosis factor receptor gene family that contributes to viral virulence. Virology 184:370382.

55.Upton, C., K. Mossman, and G. McFadden. 1985. Encoding of a homolog of the IFN- $\gamma$ receptor by myxoma virus. Science 258:13691372.

56. Vaughan, T.J., A.J. Williams, K. Pritchard, J.K. Osbourn, A.R. Pope, J.C. Earnshaw, R.A. Hodits et al. 1995. Human antibodies with sub-nanomolar affinities isolated from a large non-immunized phage display library. Nat. Biotechnol. 14:309-314.

57. Winter, G. 1998. Synthetic human antibodies and a strategy for protein engineering. FEBS Lett. 430:92-94.

58. Winter, G., A.D. Griffiths, R.E. Hawkins, and H.R. Hoogenboom. 1994. Making antibodies by phage display technology. Annu. Rev. Immunol. 12:433-455.

59.Xiang, Y. and B. Moss. 1999. Identification of human and mouse homologs of the MC51L53L-54L family of secreted glycoproteins encoded by the molluscum contagiosum poxvirus. Virology 257:297-302.

60.Xiang, Y. and B. Moss. 1999. IL-18 binding and inhibition of interferon $\gamma$ induced by human poxvirus-encoded proteins. Proc. Natl. Acad. Sci. USA 96:11537-11542.

Address correspondence to:

Dr. R. Mark L. Buller

Department of Molecular Microbiology

and Immunology

St. Louis University

Health Sciences Center

Room M410, 1402 S Grand Boulevard

St. Louis, MO 63104, USA

e-mail: bullerrm@slu.edu. 